\title{
THE IMPACT OF FISCAL DECENTRALIZATION ON INCOME AND EDUCATION INEQUALITY THROUGH ECONOMIC GROWTH IN EAST JAVA
}

\author{
Muhammad Abdul Ghofur*, Lucky Rachmawati \\ Economics Faculty, Universitas Negeri Surabaya, Surabaya, Indonesia \\ muhammadghofur@unesa.ac.id \\ luckyrachmawati@unesa.ac.id
}

\begin{abstract}
There are still many districts in East Java Province that are categorized as underdeveloped regions, which means that the region has low economic growth with a high income and education inequality. An economic model analysis that illustrates how the impact of fiscal decentralization has been exercised on income inequality and inequality of education through economic growth is needed. The analysis model used is path analysis to determine the direct and indirect impact of fiscal decentralization on income and education inequality through economic growth. The data used in the study were panel data from 2008 to 2015 collected from 29 districts in the East Java Province. The results of the study indicate that the implementation of the fiscal decentralization policy has not been able to encourage economic growth and reduce the number of income inequality and inequality of education. Decentralization makes income inequality even more intense. Economic growth has not been able to reduce the income inequality, but it can reduce the rate of education inequality.
\end{abstract}

Keywords: fiscal decentralization, educational inequality, income inequality, economic growth.

JEL classification: $124,125$.

\section{Introduction}

The priorities and direction of the spatial development policy of the East Java Province in 2014-2019 are directed towards the consolidation of the urban National Centre of Activities as a metropolitan area in East Java, the development of the Regional Activity Centre, and increasing the linkage of the main production bags in East Java Province with the processing and marketing centre as the core of agropolitan system development as well as stabilizing the development of strategic areas by dividing the strategic role of regional development (East Java Provincial Government, 2015). It is important to note that all areas in East Java Province can functionally play a role to encourage economic growth in East Java Province in general.

The economic growth of the East Java Province in the past five years has always been above national economic growth. This growth is always stable at above $5 \%$. The growth peak occurred in 2012 with a growth rate of around 6.5\%. In 2017, the economic growth (year on year) reached $5.5 \%$ above national economic growth of $5.2 \%$. However, the economic growth has not been able to push the per capita income to the middle-income limit; in 2017 the per capita income of the East Java province is still at USD 4,086; the gross domestic regional product value is USD 140 million.

Regional typology is also very important to note in formulating regional development policies, one of which was put forward by Klassen. The classification of patterns of economic development if based on Klassen Typology in the districts of East Java Province show a real inequality between regions (Soejoto et al. 2016). This in the long term will disrupt the

\footnotetext{
* Corresponding author: Muhammad Abdul Ghofur
} 
development of East Java Province as a whole, especially to the achievement of development priorities.

The success of economic development is not enough to be seen only from an economic growth perspective, despite the fact that rapid economic growth in various regions is a key driver of poverty alleviation experienced by the region. Reduced poverty figures are still not able to guarantee the closing of the gap in the community, especially when the availability of natural resources is reduced and the rate of economic growth slows down.

Based on the neo-Classical opinion at the beginning of the development process, the development inequality between regions tends to increase. This process will continue to occur until inequality reaches its peak. If the development process continues then gradually, the development inequality between regions will decline. According to Williamson (1965), indirect economic development can reduce the level of inequality, but in the early stages, the opposite has occured. Kuznets (1955) said that in the early stages of economic growth, income distribution would deteriorate, but at a later stage, income distribution would increase.

The inequality of people's incomes will reduce the benefits of growth, whereby the greater the level of income inequality, the lower the impact of growth on poverty alleviation. Income inequality will also affect the inequality of education and the family social environment, even in developed countries like America. Increased income gaps are related to the gap in the amount of money spent by low-income and high-income parents in educational enrichment activities for their children (Duncan and Murnane 2014). As a result, there is a difference in the level of learning achievement of children with low-income and high-income parents. At a higher education level is similar where there are differences in the level of college graduation in low and high-income families. McKeever's (2017) research conclusions also show no difference.

The decentralization policy that has been implemented in Indonesia since 2001 is an appropriate first step, in which the implementation of this policy is expected to reduce the various inequities that exist. In their study, Tselios et al. (2012) analyse the impact of decentralization policies in the EU. The results of the analysis show that greater fiscal decentralization is associated with low-income inequality, as regional revenues increase. Further decentralization is correlated with a decrease in inequality.

After more than a decade of implementation of decentralization policy in East Java Province, there is no region/city that can be classified as a developed and growing region. Although there is region/city in East Java Province with high economic growth as well as larger balancing funds than other districts, there are still significant disparities in income or educational inequality. A region has low economic growth with the condition of income inequality and inequality of higher education and right now, a great number of regions are categorized as being very lagging regions. How the impact of fiscal decentralization on income inequality and inequality of education is of key importance, especially in an effort to improve the prosperity of society by seeking a significant and stable economic growth.

A study undertaken by Lessmann (2012) suggests that while overall fiscal decentralization policies are capable of reducing inequality, but in the case of developing countries decentralization policies can trigger inequality between regions. Despite this, decentralization generally generates regional prosperity. The study on the effectiveness of the implementation of decentralization in various regions in the East Java Province is expected to show how the characteristics and direction of it impacts economic growth, especially related to income inequality and education.

Both income inequality and inequality of education, in the long run, will determine the quality of human capital. In developing countries, the quality of human capital is a key element of economic development. A person's level of education will determine their income level in the 
future. The education level of the general population also determines the competitiveness of the developing country.

\section{Research Methods}

The method used in this research is a quantitative method given that the research is based on quantitative data (VanderStoep and Johnston 2009). This study belongs to the category of causal relationship studies because it aims to explain the causal relationship between variables through hypothesis testing (Bordens and Abbott 2013).

Fiscal decentralization is measured by the amount of the balance fund consisting of profit-sharing funds originating from taxes and natural resources, general allocation funds, and special allocation funds for each district in the East Java Province. Economic growth is measured through gross regional domestic product year on year with the following formula: Growth $=\frac{Y_{t}-Y_{t-1}}{Y_{t-1}} \times 100 \%$

Income and education inequality are measured using the Gini index with the following formulations:

$\operatorname{gini}_{\text {income }}=1-\sum_{i=1}^{n} f_{i}\left(Y_{i+1}+Y_{i}\right)$

gini incotn $_{\text {: }}$ : Gini index

$f_{i} \quad$ : proportion of the number of households in one class $i$

$r_{i} \quad$ : proportion of the total cumulative household income in class $\mathrm{i}$

Testing the effect of fiscal decentralization variable $\left(X_{1}\right)$ on income inequality $\left(Y_{2}\right)$ and educational inequality $\left(Y_{3}\right)$ through economic growth $\left(Y_{1}\right)$ in the East Java Province has been done by using path analysis. Path analysis is a multivariate analysis technique that allows researchers to examine the relationship between complex variables either directly or indirectly to obtain a comprehensive picture of the relationships between variables in a model. In path analysis, there are two categories of common variables: exogenous and endogenous variables. Exogenous variable in this research model is the fiscal decentralization variable. While the endogenous variable is income inequality variable, education is an inequality variable, and a variable of economic growth. The research model used is illustrated in Figure 1.

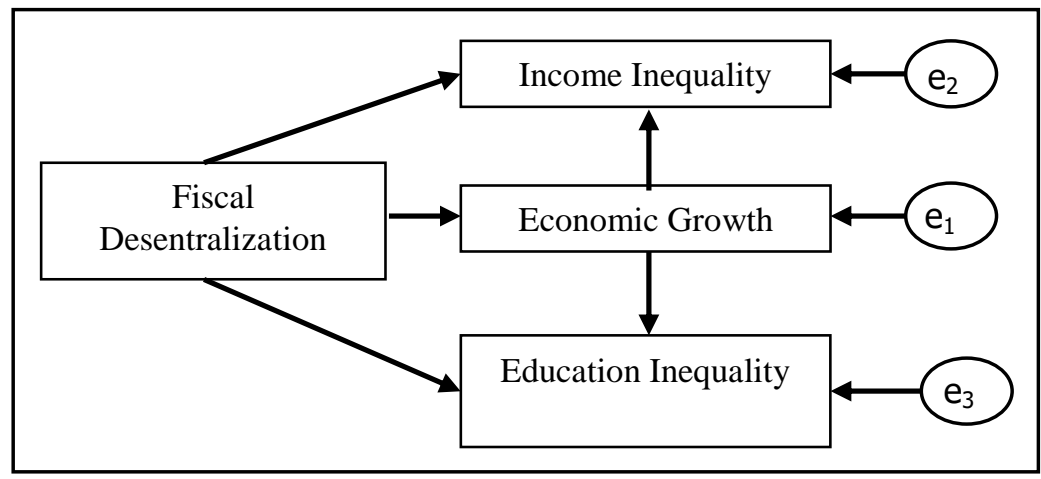

Figure 1: Conceptual Framework 
Based on the conceptual framework, the following model is obtained,

$$
\begin{aligned}
& Y_{1}=\rho_{X_{1} Y_{1}} X_{1}+e_{1} \\
& Y_{2}=\rho_{X_{1} Y_{2}} X_{1}+\rho_{Y_{1} Y_{1}} Y_{1}+e_{2} \\
& Y_{3}=\rho_{X_{1} Y_{s}} X_{1}+\rho_{Y_{2} Y_{1}} Y_{1}+e_{3}
\end{aligned}
$$

where $X_{1}$ is fiscal decentralization; $Y_{2}$ is income inequality; $Y_{3}$ is educational inequality; $Y_{1}$ is the economic growth; $\rho_{X_{i} Y_{j}}$ is the path coefficient; and ER is the error term

The data used in the study was obtained from panel data from 2008 to 2015 collected from 29 districts in the East Java Province, while 9 urban areas were not included in the analysis due to differences in growth characteristics and inequality.

\section{Results and Discussion}

The model analysis using path analysis begins with the goodness of fit model analysis. This analysis is done by looking at some test model criteria. Some of the goodness of fit test criteria can be grouped into three groups of test measures: absolute fit measures, incremental fit measures, and parsimonious fit measures. Absolute fit measures are performed by looking at the value of Chi-Square $\left(X^{\wedge} 2\right)$. This Chi-Square value determines the probability value $(P)$. In the conformity test of the maximum likelihood-based model, it is expected that the value of $X^{\wedge} 2$ is small so that the $P$ value is greater than $\alpha(0.05)$. The value of $X^{\wedge} 2$ in the calculation result is 66,205 (prob. 0.000) which means not fulfilment of the absolute fit measures.

Besides the Chi-Square values, there are another two absolute fit measures, i.e. Goodness of fit index (GFI) and Root Mean Square Error of Approximation (RMSEA). The GFI value in this model is 0.89 , while the GFI size for the acceptable model is at least 0.9. The RMSEA value of this model is 0.521 with the expected value is 0.08 .

Incremental fit measures include Adjusted Goodness of Fit Index (AGFI), Normed Fit Index (NFI), Comparative Fit Index (CFI) and several other measures. The AGFI score obtained in this model is -0.076 with an expected value of at least 0.9 to meet incremental fit criteria. While at the value of NFI obtained results of 0.247 with the suitability of the model or fit model if $\mathrm{NFI}$ at least 0.9 . For $\mathrm{CFI}$ values the model is generated at 0.204 from the minimum value of 0.0 and maximum 1.0. The model is said to be fit when the CFI value is at least 0.9 . Parsimonious fit measures are performed by looking at the values of Parsimonious Normed Fit Index (PNFI), Parsimonious Goodness Fit Index (PGFI), and Akaike Information Criterion (AIC). The output value of PNFI of this structural model is 0.041 while the minimum criterion is 0.9. At the value of PGFI obtained results of 0.089 . Similar to the PNFI criterion, the larger PGFI values show a good model with a minimum limit of 0.9 . For the value of AIC obtained a value of 124.568 . The smaller the AIC value indicates the model the more parsimony. The output image of the structural model is presented in Figure 2. 


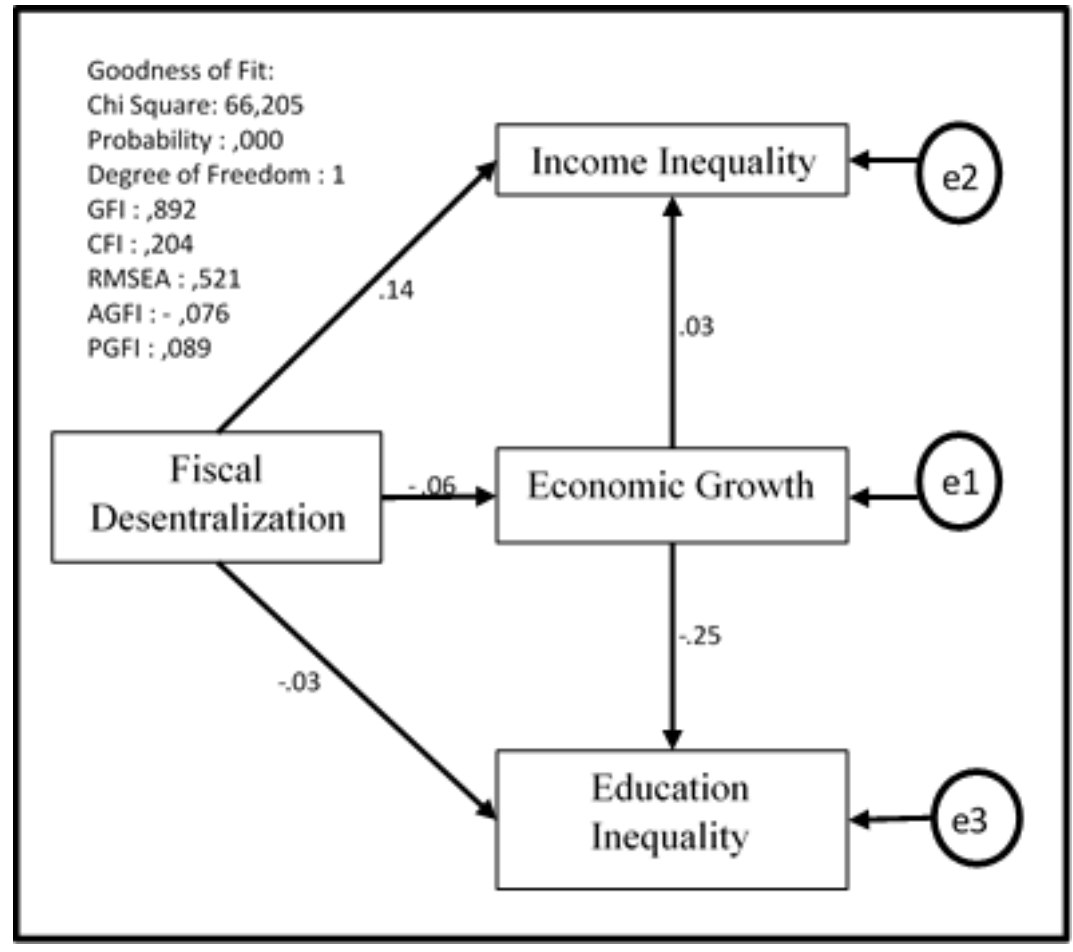

Figure 2: Output of Research Model (2018)

Overall, when looking at the various criteria of goodness of fit model, then it can be said that this model is not yet fit. This indicates that the fiscal decentralization policies implemented in various regions of East Java generally have diverse effects on economic growth, income inequality and inequality of education. The implications of implementing this diverse fiscal decentralization policy are in line with the characteristics of the impact of decentralization policies in developing countries. The results of Lessmann's (2012) research can at least be used as a reference $\mathrm{f}$; the implementation of decentralization policies in developing countries have varying implications depending on local resources, government readiness and geographical and demographic conditions of the community. The results of Sepulveda and Martinez-Vazquez (2011) also present conclusions that are not much different: where the regional competencies also determine the direction of the impact of decentralization.

The linkage between research variables is partially further analysed to find out a fuller picture of how decentralization policies work. But before that will happen, we need to statistically see how exogenous variables influence endogenous variables.

The results of the complete path coefficient statistical tests are: 
Table 1: Test of Path Coefficient Statistics

\begin{tabular}{|l|l|l|l|l|}
\hline Path & $\begin{array}{l}\text { Path } \\
\text { Coeff. }\end{array}$ & t-stat. & Prob. & Note \\
\hline $\begin{array}{l}\text { Fiscal } \\
\text { Decentralization }\left(\mathrm{X}_{1}\right) \\
\rightarrow \text { Economic } \\
\text { Growth }\left(\mathrm{Y}_{1}\right)\end{array}$ & $-0,060$ & $-0,928$ & 0,353 & $\begin{array}{l}\text { Small Influence / } \\
\text { Not Significant }\end{array}$ \\
\hline $\begin{array}{l}\text { Fiscal } \\
\text { Decentralization }\left(\mathrm{X}_{1}\right) \\
\rightarrow \text { Income } \\
\text { Inequality }\left(\mathrm{Y}_{2}\right)\end{array}$ & 0,141 & 2,209 & 0,027 & Significant \\
\hline $\begin{array}{l}\text { Fiscal } \\
\text { Decentralization }\left(\mathrm{X}_{1}\right) \\
\rightarrow \text { Education } \\
\text { Inequality }\left(\mathrm{Y}_{3}\right)\end{array}$ & $-0,031$ & $-0,502$ & 0,616 & $\begin{array}{l}\text { Small Influence / } \\
\text { Not Significant }\end{array}$ \\
\hline $\begin{array}{l}\text { Economic } \\
\text { Growth }\left(\mathrm{Y}_{1}\right)\end{array}$ & 0,029 & 0,454 & 0,650 & $\begin{array}{l}\text { Small Influence / } \\
\text { Income } \\
\text { Inequality }\left(\mathrm{Y}_{2}\right)\end{array}$ \\
\hline $\begin{array}{l}\text { Economic } \\
\text { Growth }\left(\mathrm{Y}_{1}\right) \\
\text { Education } \\
\text { Inequality }\left(\mathrm{Y}_{3}\right)\end{array}$ & $-0,253$ & $-4,052$ & 0,000 & Significant \\
\hline
\end{tabular}

From the results of the path coefficient test in the table when described into three output equations namely:

$Y_{1}=-0,060 X_{1}+e_{1}$

$Y_{2}=0,141 X_{1}+0,029 Y_{1}+e_{2}$

$Y_{3}=-0,031 X_{1}-0,253 Y_{1}+e_{3}$

The result of significance test of the coefficient of the decentralized variable path on economic growth shows a small but negative value. The influence is not proven significant but needs to be further examined because one of the main goals of decentralization is to create community prosperity. The decentralization policy has not been able to contribute significantly to economic growth in East Java. The inability of regions to maximize decentralization funds becomes more apparent. East Java's economic growth in recent years is very good and always higher than the national economic growth (Central Agency on Statistics, 2014).

The results of studies conducted by Herath (2009) provide evidence that while theoretically, decentralization promotes economic growth, empirically it is often inappropriate. The implementation of decentralization policy in Sri Lanka with a low level of decentralization is still in fact low and unable to increase per capita income. This is due to the lack of regional competence to take advantage of decentralization policies. It is also related to the readiness of local resources in managing the advantages of their respective regions. In a developing country like Indonesia, this is a natural situation where regional competence differences in managing their resources determines the success of economic development.

Differences in regional capabilities and resources in East Java have made the impact of decentralization policy in general not yet able to stimulate economic growth (Huda and Santoso 2014; Priyambodo, Luthfi, and Santoso 2015). There are still many local 
governments in East Java who have not been able to convert their financial capacity into programs that are able to encourage economic growth in their regions.

The effect of decentralization policy on income inequality is shown on the lane coefficient value of 0.141 with a probability of 0.027 . A probability value below 0.05 indicates that the effect is convincing. The positive line coefficient shows that fiscal decentralization policy encourages income inequality in various regions. This can be explained by reference to the Sepulveda and Martinez-Vazquez (2011) studies which conclude that the impact of fiscal decentralization on income inequality depends on the economic size of a region. If the overall size of the economy is relatively small then decentralization encourages the distribution of income to deteriorate. As well as the research at the district government level in East Java, the current decentralization policy has not been able to address the wider community.

The positive impact of decentralization is still enjoyed by a small number of communities. A large number of regional heads involved in corruption cases also contributes to the indication that the positive benefits of decentralization is still enjoyed by those close to power. This is also contributing to sharpen the inequality of income in the region. The implementation of decentralization policy in Turkey deserves to be taken into consideration where local people have not been able to effectively respond to local government policies. The policy of decentralization without being followed by adequate administrative remedies will not be able to suppress inequality, instead, it will trigger new social problems (Özcan 2006).

The contribution of decentralization policy to education inequality is still very small, although there is an indication of the contribution of this policy to the reduction of the education gap in East Java. The coefficient value of the lane is -0.031 and not significant at the probability value of 0.616 . It indicates that the effect of this decentralization on the decrease in inequality of education is still very small. If in the short-term decentralization has not been able to reduce the level of educational inequality, but the direction of the impact of this policy has begun to be seen with a negative coefficient. Due to the variety of educational conditions and problems in different districts, to see in detail the impact of decentralization on educational inequality requires a separate analysis in each region using long-term analysis. The contribution of economic growth to income inequality in this study shows very small value with 0.029 path coefficient and the probability is 0.650 . This condition suggests that high economic growth in East Java has not been felt equally by all levels of society. Growth concentrations still occur only in certain areas, especially in urban areas. The development policy implemented has not been able to touch the mainstay sectors in each region.

Economic growth was able to reduce the level of education inequality significantly. The coefficient of economic growth path on the educational inequality is -0.253 with a probability value of 0.000 . Thus, empirically in East Java, it is proved that economic growth can reduce the rate of education inequality. This is very important in order to improve the quality of human capital of East Java in order to improve the prosperity in the future and continue to strengthen the position of competitiveness of East Java.

Good economic growth and sustained awareness will contribute significantly to the decline in inequality of education in East Java. Although decentralization has not been able to contribute significantly to the growth of the economy and reduce the rate of educational inequality, at least the direction of this policy has begun to be seen. As suggested by Sepulveda and Martinez-Vazquez (2011), increasing decentralization figures or above $20 \%$ of APBD will be felt only by regional impacts in developing countries. It is hoped that the power of good social capital will stimulate interpersonal trust, interpersonal cooperation, and social cohesion (De Mello 2004). Therefore, the region will have a more efficient government with a better government system, which can eventually grow even faster. 


\section{Conclusion}

The implementation of a fiscal decentralization policy in the regency of the East Java province has not been able to encourage economic growth and to reduce the size of income inequality and educational inequality. Interestingly, it is precisely this decentralization policy that makes income inequality increasingly sharp. Local governments have not been able to make development policies that can effectively respond to all levels of society. Economic growth has not been able to reduce income inequality. The effects of economic growth are still felt by a small number of people, thus potentially widening the gap. On the one hand, economic growth is able to encourage equitable access to education so that the rate of education inequality can be suppressed. Consequently, the contribution of a decentralization policy cannot be felt directly for the moment and the increase in the decentralization rate is believed to have a positive effect in the long term, Of course, it should be accompanied by improvement of administrative system and improvement of regional competence in regards to managing its finances.

\section{References}

Bordens, K.S., and Abbott, B.B., 2013. Research Design and Methods: A Process Approach. 9th ed., New York: McGraw-Hill Education.

De Mello, L.R. 2004. Can Fiscal Decentralization Strengthen Social Capital?. Public Finance Review 32 (1). SAGE Publications, pp. 4-35. doi:10.1177/1091142103260699.

Duncan, G. J., and Murnane, R.J.. 2014. Growing Income Inequality Threatens American Education. Phi Delta Kappan, 95 (6). Los Angeles, CA: SAGE Publications, pp. 8-14. doi:10.1177/003172171409500603.

Herath, Tikiri Nimal. 2009. Decentralization of Governance and Economic Development. South Asia Economic Journal 10 (1). New Delhi, India: SAGE Publications, 10 (1), pp. 157-185, doi:10.1177/139156140901000107.

Huda, Miftakhul, and Eko Budi Santoso. 2014. Pengembangan Daya Saing Daerah Kabupaten/Kota Di Propinsi Jawa Timur Berdasarkan Potensi Daerahnya. Jurnal Teknik ITS 3 (2): C81-86. doi:10.12962/j23373539.v3i2.7207.

Kuznets, S., 1955. Economic Growth and Income Inequality. The American Economic Review 45 (1). American Economic Association, pp. 1-28. doi:10.2307/1811581.

Lessmann, C., 2012. Regional Inequality and Decentralization: An Empirical Analysis. Environment and Planning A: Economy and Space 44 (6). London, England: SAGE Publications pp. 1363-1688. doi:10.1068/a44267.

McKeever, M., 2017. Educational Inequality in Apartheid South Africa. American Behavioral Scientist, 61 (1). Los Angeles, CA: SAGE Publications, pp. 114-131, doi:10.1177/0002764216682988.

Özcan, Gül Berna. 2006. A Critical Analysis of Decentralisation and Local Economic Development: The Turkish Case. Environment and Planning C: Government and Policy 24 (1), pp. 117-138. London, England: SAGE Publications, doi:10.1068/c0439.

Priyambodo, Kukuh Danuargo, Agus Luthfi, and Edy Santoso. 2015. Analisis Disparitas Pendapatan Kabupaten Dan Kota Di Provinsi Jawa Timur. E-Journal Ekonomi Bisnis Dan Akuntansi, 2 (1), pp. 28-36. doi:10.19184/ejeba.v2i1.1403.

Sepulveda, C.F. and Jorge Martinez-Vazquez. 2011. The Consequences of Fiscal Decentralization on Poverty and Income Equality. Environment and Planning C: Government and Policy, 29 (2), pp. 321-43. doi:10.1068/c1033r.

Soejoto, Ady, Dhiah Fitrayati, Lucky Rachmawati, and Ni'matush Sholikhah. 2016. Typology of Regional Economic Development Pattern. International Journal of Applied Business and Economic Research, 14 (13), pp. 9493-9505. 
Tselios, V., Rodríguez-Pose, A., Pike, A., Tomaney, J. and Torrisi, G., 2012. Income Inequality, Decentralisation, and Regional Development in Western Europe. Environment and Planning A: Economy and Space, 44 (6), pp. 1278-1301, doi:10.1068/a44334.

VanderStoep, S.W., and Johnston, D.D., 2009. Research Methods for Everyday Life: Blending Qualitative and Quantitative Approaches, San Francisco, CA: Jossey-Bass.

Williamson, J.G. 1965. Regional Inequality and the Process of National Development: A Description of the Patterns. Economic Development and Cultural Change 13 (4), pp. 1-84. doi:10.2307/1152097.

\section{Bio-note}

Muhammad Abdul Ghofur, is a lecturer in the Universitas Negeri Surabaya and a doctoral student in the Universitas Negeri Malang and member of the several research teams developed within the projects implemented by our Faculty. As a researcher, Ghofur focused on economics education and macroeconomic policy.

Lucky Rachmawati, Dr., is a lecturer in the Universitas Negeri Surabaya and member of the several research teams developed within the projects implemented by our Faculty. As a researcher, Lucky focused on human resources economics, especially about the quality of human capital. 